\title{
Informed consent in neurosurgery: a systematic review
}

\author{
Nathan A. Shlobin, BA, ${ }^{1}$ Mark Sheldon, PhD, ${ }^{2,3}$ and Sandi Lam, MD, MBA ${ }^{1}$ \\ 1Department of Neurological Surgery, Northwestern University Feinberg School of Medicine, Division of Pediatric Neurosurgery, \\ Anne and Robert H. Lurie Children's Hospital, Chicago; '2Department of Philosophy, Northwestern University, Evanston; and \\ ${ }^{3}$ Center for Bioethics and Medical Humanities, Northwestern University Feinberg School of Medicine, Chicago, Illinois
}

OBJECTIVE Informed consent has served as a main principle of medical ethics and laws in the United States. The 1986 American Association of Neurological Surgeons Code of Ethics implied medicolegal liability for the failure to obtain informed consent without providing practical guidance regarding the application of informed consent to individual patient encounters in a medicolegal environment. Here, the authors aimed to identify baseline patient recall after discussions with neurosurgeons and their capacity to provide informed consent, describe the effects of interventions to improve patient comprehension, and elucidate the role of informed consent in malpractice litigation in neurosurgery. Their findings may guide neurosurgeons in discussions to properly inform patients and reduce the risk of litigation.

METHODS A systematic review was conducted to explore informed consent within neurosurgery and its application to medicolegal liability using the PubMed, Embase, and Scopus databases. Titles and abstracts from articles identified in the search were read and selected for full-text review. Studies meeting prespecified inclusion criteria were reviewed in full and analyzed for study design, aim, population, interventions, and outcomes.

RESULTS Of 1428 resultant articles, 21 were included in the review. Baseline patient recall was low, particularly for risks and alternatives of treatments, and even decreased over time. Cognitive impairment was noted as a factor limiting the ability to provide informed consent. Interventions incorporating a combination of modalities in informed consent discussions, a specialized consent form with points for neurosurgeons to check off upon discussion, interactive websites, question prompt lists, and illustrations were found to be effective in improving patient knowledge. Lack of informed consent was a common factor for malpractice litigation. Spine surgery was particularly prone to costly lawsuits. Payments were generally greater for plaintiff verdicts than for settlements.

CONCLUSIONS The application of informed consent to patient encounters is an important facet of clinical practice. Neurosurgeons have a duty to provide patients with all pertinent information to allow them to make decisions about their care. The authors examined baseline patient comprehension and capacity, interventions to improve informed consent, and malpractice litigation; it appears that determining the proper capacity to provide informed consent and considering informed consent as a process that depends on the setting are important. There is room to improve the informed consent process centered on baseline patient health literacy and understanding as well as clear communication using multiple modalities.

https://thejns.org/doi/abs/10.3171/2020.8.FOCUS20611

KEYWORDS decision-making; informed consent; medical malpractice; medicolegal; neurosurgery

I NFORMED consent, the process of communication between physician and patient to provide the patient with the knowledge to make decisions regarding care, has served as a main principle of medical ethics and laws in the United States since the 1970s. ${ }^{1-3}$ In 1986, the American Association of Neurological Surgeons revised its Code of Ethics to include principlism given the perception of the Hippocratic Oath and older codes as insufficient in describing the patient-physician relationship., ${ }^{1,4}$ The Code of Ethics introduced autonomy, defined as individual freedom of choice, into the neurosurgical lexicon as a response to pa- ternalistic practices and noted informed consent as an example of the conflict between ethical theory and practice.1,4

However, the code neither described the intricacies of informed consent nor provided practical guidance regarding the application of informed consent to patient encounters. ${ }^{1}$ The code also implied legal penalties to neurosurgeons such as financial damages or loss of licensure if informed consent did not occur. ${ }^{1-3}$ The application of informed consent in practice is not uniform. ${ }^{1,5}$ In daily practice, there may be unnecessary exposure to medicolegal liability. ${ }^{1,6}$

Given the lack of synthesis of informed consent in neu- 
rosurgical practice, we conducted a systematic review on the nature of informed consent and the medicolegal aspects of informed consent in neurosurgery. We aimed to 1) identify baseline recall after standard informed consent discussions with neurosurgeons, 2) describe the effect of interventions to improve patient understanding, and 3) elucidate the role of informed consent in malpractice litigation aimed at neurosurgeons. Our findings may guide neurosurgeons in their discussions to properly inform patients and reduce the risk of litigation.

\section{Methods}

A systematic review was performed in accordance with the PRISMA guidelines to investigate informed consent in neurosurgery? The PubMed MEDLINE (National Library of Medicine), Embase (Elsevier), and Scopus (Elsevier) databases were searched in June 2020. The protocol for this systematic review was not registered. Databases were queried using the search terms "informed consent" AND ("neurosurgery" OR "neurological surgery") for PubMed, "informed consent':ti,ab,kw AND ('neurosurgery':ti,ab,kw OR 'neurological surgery':ti,ab,kw) for Embase, and TITLEABS-KEY ("informed consent" AND ("neurosurgery" OR "neurological surgery")) for Scopus. No restrictions on language, date, or article type were applied.

After completing the search, duplicates were excluded. All remaining articles were screened by title and abstract. Articles included for full-text review were screened for final inclusion based on the following criteria: published in or translated into the English language, with the full text available, describing neurosurgeons or neurosurgical patients, and providing quantitative information regarding informed consent processes or medicolegal issues associated with informed consent.

Outcomes were prespecified. Primary outcomes included patient recall of aspects of informed consent discussions, effect of informed consent interventions on patient recall, and proportion of malpractice litigation implicating a lack of proper informed consent. Secondary outcomes were designation of decision-making capacity and malpractice litigation due to other reasons. A second reviewer replicated the search strategy, and disagreements were reconciled.

After a final exclusion of articles not meeting the inclusion criteria, all included articles were reviewed for bibliographic data, design, study participants, interventions, and outcome data.

The World Bank income status classification was used to denote an income level for the country of origin of each included study. ${ }^{8}$ Studies were divided into the following categories for analysis: comprehension and capacity, interventions, and medicolegal aspects.

Critical appraisal of the included studies was adapted from study design grades delineated by Shadish et al. ${ }^{9}$ Grades are described in Table 1, and grade E studies were excluded. The Risk of Bias in Non-randomised Studies of Interventions (ROBINS-I) tool was used to assess the risk of bias for each included study. ${ }^{10} \mathrm{~A}$ judgment for the overall risk of bias for this systematic review was determined based on the risk of bias for each included study.
TABLE 1. Grading of study design quality

\begin{tabular}{|c|c|}
\hline Grade & Design \\
\hline AA & Systematic review or meta-analysis of RCTs \\
\hline \multirow{2}{*}{$A$} & Systematic review or meta-analysis of non-RCTs \\
\hline & RCT or cluster RCT \\
\hline \multirow{6}{*}{ B } & $\begin{array}{l}\text { Systematic review or meta-analysis of controlled studies w/o } \\
\text { pretest or uncontrolled study w/ pretest }\end{array}$ \\
\hline & Non-RCT \\
\hline & Controlled before-\&-after study \\
\hline & Retrospective or prospective cohort study \\
\hline & Interrupted time series \\
\hline & Case-control study \\
\hline \multirow{2}{*}{ C } & Systematic review or meta-analysis of cross-sectional studies \\
\hline & Uncontrolled before-\&-after study \\
\hline D & Cross-sectional study, models \\
\hline$E$ & Case studies, case reports, narrative reviews \\
\hline
\end{tabular}

$\mathrm{RCT}=$ randomized controlled trial.

\section{Results}

The search identified 1428 articles, 21 of which were included in this systematic review. ${ }^{11-31}$ Figure 1 shows our PRISMA flowchart for article selection. No randomized controlled trials were identified. Study designs included nine (42.9\%) retrospective cohort studies, five (23.8\%) prospective cohort studies, five (23.8\%) uncontrolled beforeand-after studies, one (4.8\%) controlled before-and-after study, and one (4.8\%) cross-sectional study. Most studies had a moderate risk of bias, predisposing our review to a moderate risk of bias overall.

Eight (38.1\%) studies examined informed consent in the medicolegal setting, seven (33.3\%) assessed knowledge or capacity of neurosurgical patients, and six $(28.6 \%)$ examined informed consent interventions to improve patient understanding. Articles originated from eight countries, all high-income countries. Figure 2 identifies countries of origin. The United States was the country of origin for nine studies, followed by the United Kingdom with four studies and Germany and Japan with two studies each. Details of each included study are listed in Table 2.

\section{Baseline Recall and Capacity}

Seven studies examined baseline characteristics for informed consent by neurosurgical patients. ${ }^{17-19,21,23,25,31}$ Five of these studies examined recall. ${ }^{17,21,23,25,31}$ One study found that patients receiving education about anterior cervical fusion or lumbar laminectomy answered $43.5 \%$ of questions correctly on a test immediately after the discussion. ${ }^{17}$ Another study found that patients recalled, on average, 5 of 32 risks pertaining to cranial surgery and 4 of 25 risks pertaining to spine surgery and $18 \%$ of all general information, whereas $65 \%$ of patients did not recall more than 2 of 6 typical major risks of surgery. ${ }^{23}$ An additional study found that $29 \%$ of patients did not recall any risks of a trial neurooncology drug, whereas those who were able to remember specific risks recalled at most 4 risks. ${ }^{21}$ Another study found variation in the recall of risks after discussions 


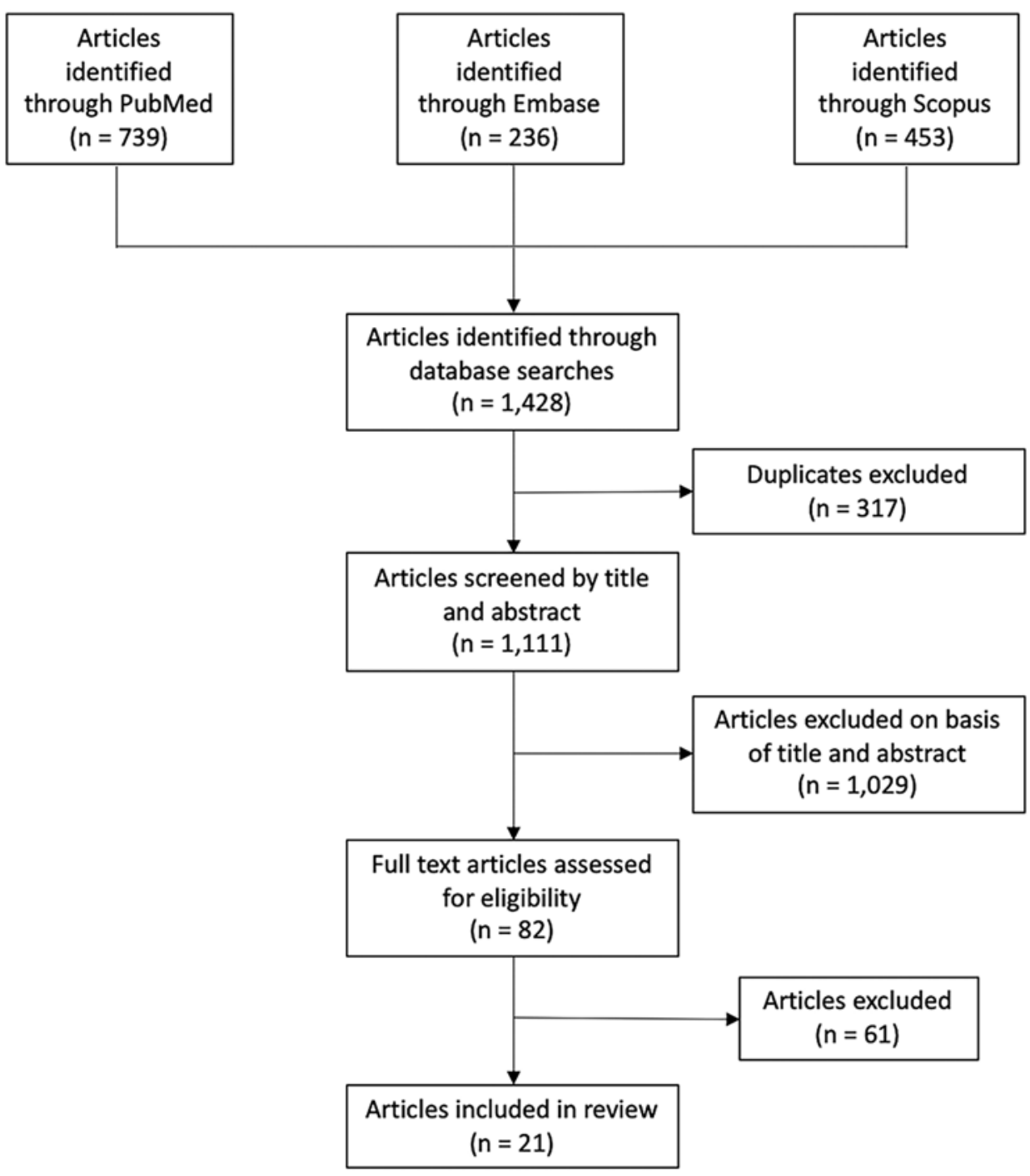

FIG. 1. PRISMA flowchart outlining the search and review process used to identify and select articles for inclusion in this systematic review.

of lumbar spinal surgery based on the type of risk, with recall greatest for paralysis (50.9\%) and lowest for recurrence $(6.5 \%){ }^{25}$ However, one study examining pediatric neurosurgery consent in a single department determined that all parents (or patients when appropriate) believed an informed decision had been made and the primary diagnosis and type of surgery were understood, that $98 \%$ understood procedure-specific risks, and that $84 \%$ remembered the mention of the general risks of surgery, although only $24 \%$ remembered the discussion of alternative forms of management, including no treatment. ${ }^{31}$

Two studies examined the capacity to provide informed consent. ${ }^{18,19}$ In one, $3.6 \%$ of patients with intracranial tumors and seen over 2 years were deemed incapable of providing informed consent, $77.8 \%$ of whom had high-grade glioma. ${ }^{19}$ Cognitive assessment was documented in $19 \%$ of all patients, $15.8 \%$ of whom were labeled as unable to provide consent. In the other study, $80 \%$ of patients with acute anterior circulation stroke were incapable of provid- ing informed consent to participate in a trial of endovascular intervention using mild criteria on admission, whereas $60 \%$ were incapable of providing informed consent at 24-48 hours after admission. ${ }^{18}$

\section{Interventions to Improve the Informed Consent Process}

Six studies examined interventions to improve the process of informed consent. ${ }^{15,22,24,27,29,30}$ One study found that scores on a questionnaire assessing the knowledge of patients with cervical spondylitic myelopathy caused by posterior longitudinal ligament ossification were greater in patients undergoing an educational and interactive consent process consisting of information booklets, video, verbal information, and two physician-patient interviews than in the patients having one physician-patient interview. ${ }^{24}$ A study incorporating a specialized consent form with points for neurosurgeons to check off upon discussion found that $100 \%$ of patients correctly recalled their 


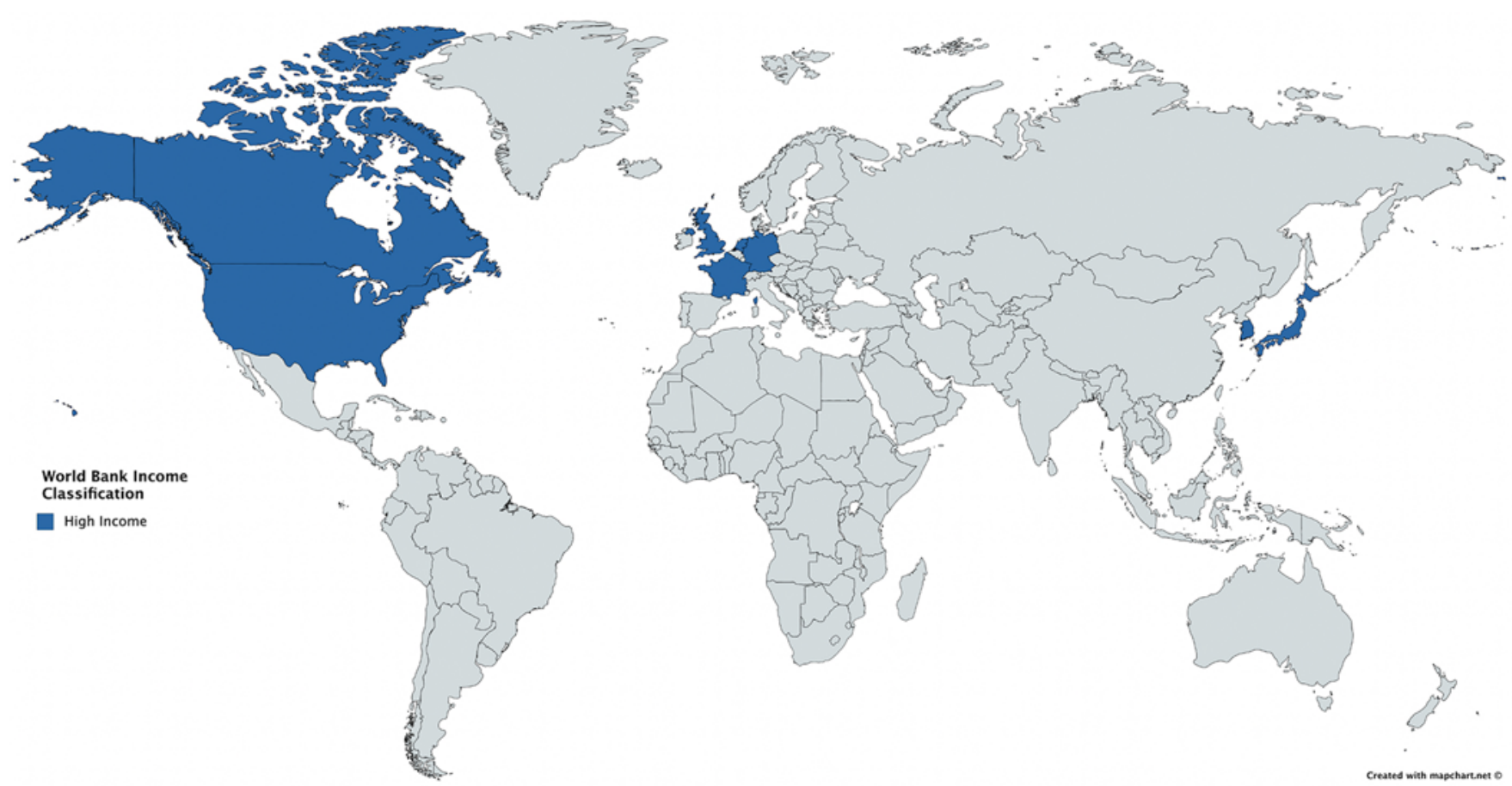

FIG. 2. Map showing the countries represented by the studies included in this systematic review. The map was made using mapchart.net. CC BY-SA 4.0 (https://creativecommons.org/licenses/by-sa/4.0/).

diagnosis and planned procedure, while $98.1 \%$ of alternative treatments and $97.4 \%$ of risks were recalled correctly. ${ }^{22}$ Scores on a questionnaire assessing the knowledge of patients undergoing transsphenoidal excision for pituitary adenoma were greater after the introduction of an interactive educational website than before its introduction. ${ }^{27}$ Another study found that adult spinal deformity patient recall was $45 \%$ immediately after discussion and video reinforcement regarding surgery, even though the patients described the consent process as important. ${ }^{30}$

One study involved the creation of a question prompt list with sections including preoperative inpatient stay and organizational issues, safety of the surgical procedure, complications and possible postoperative deficits, and prognosis and follow-up, finding internal consistency for all sections..$^{29}$ The greatest portion of unmet information needs fell under prognosis and follow-up, while the item with the greatest unmet information need was the professional experience of the surgeon..$^{29}$ Another study determined that visual explanatory aids, illustrations, and infographics were considered useful or very useful for understanding brain function and anatomy by $81.3 \%$ of respondents, for understanding pathology of disease by $75.0 \%$, and in helping to clarify physician explanations by $68.8 \% .^{15}$

\section{Medicolegal Implications of Informed Consent}

Eight studies examined informed consent in the medicolegal setting, ${ }^{11-14,16,20,26,28}$ and 7 of them examined informed consent as a reason for medical malpractice suits. ${ }^{11-14,20,26,28}$ One study from Japan reported that a lack of informed consent was implicated in $26.9 \%$ of decisions in favor of the plaintiff from 2001 to 2015 , as compared to $26.9 \%$ for clinical management, $19.2 \%$ for technical skills, and $15.4 \%$ for negligence in diagnosis. ${ }^{28}$ A study from the United States found that a lack of informed consent was the second most common reason for malpractice litigation among patients undergoing brain tumor surgery (24.4\% of cases), behind a failure to diagnose (28.0\% of cases) ${ }^{20}$ Other studies determined that a lack of informed consent was the third most common reason for litigation, $, 11,13,14$ while others found that litigation on grounds of lack of informed consent was less common. ${ }^{12,26}$ One study found that a lack of informed consent was implicated in cranial cases more often than in spinal cases. ${ }^{13}$ Median or mean payments were greater for plaintiff verdicts than for the settlements for spine surgery malpractice cases, ${ }^{11,14}$ whereas payments for settlements were greater than those for plaintiff verdicts for endoscopic sinus surgery. ${ }^{12}$

Four studies examined spine surgery.11,14,16,26 One of them determined that a lack of informed consent was the reason for the lawsuit in $42.6 \%$ of cases involving quadriplegia after cervical spine surgery in the United States, behind negligent surgery at $87.0 \%$ of cases and failure to diagnose or treat at $61.1 \%$ of cases, with total mean payments of \$5.9 million for plaintiff verdicts and \$2.8 million for settlements. ${ }^{14}$ Another study found that a lack of informed consent was a factor in $24.4 \%$ of all spine surgery malpractice cases, as compared to a failure to diagnose at $31.6 \%$ of cases and a failure to treat at $32.7 \%$ of cases, with total median payments of $\$ 2.5$ million for plaintiff verdicts and $\$ 1.3$ million for settlements. ${ }^{11}$ A study from the United Kingdom found that a lack of informed consent was noted in $8.1 \%$ of cases compared to judgment or tim- 
TABLE 2. Studies included in the review

\begin{tabular}{|c|c|c|c|c|c|c|c|}
\hline Category & Study & $\begin{array}{l}\text { Study } \\
\text { Design }\end{array}$ & Grade & $\begin{array}{l}\text { Risk of } \\
\text { Bias }\end{array}$ & Country & $\begin{array}{c}\text { Income } \\
\text { Classification }\end{array}$ & Key Findings \\
\hline \multirow[t]{7}{*}{$\begin{array}{l}\text { Compre- } \\
\text { hension \& } \\
\text { capacity }\end{array}$} & $\begin{array}{l}\text { Herz et } \\
\text { al., } 1992^{17}\end{array}$ & $\begin{array}{l}\text { Uncon- } \\
\text { trolled } \\
\text { before } \\
\& \text { after }\end{array}$ & C & $\begin{array}{l}\text { Moder- } \\
\text { ate }\end{array}$ & US & High & $\begin{array}{l}\text { Immediate performance on test after discussion w/ physician about } \\
\text { anterior cervical fusion or lumbar laminectomy was } 43.5 \% \text {; } \\
\text { performance was } 38.4 \% \text { on test } 6 \text { wks later }\end{array}$ \\
\hline & $\begin{array}{l}\text { Janssen } \\
\text { et al., } \\
2019^{18}\end{array}$ & $\begin{array}{l}\text { Prospec- } \\
\text { tive } \\
\text { cohort }\end{array}$ & B & Low & $\begin{array}{l}\text { Nether- } \\
\text { lands }\end{array}$ & High & $\begin{array}{l}96 \% \text { \& } 80 \% \text { of patients deemed not capable of decision-making } \\
\text { for trial participation on admission \& } 79 \% \text { \& } 60 \% \text { at } 24-48 \mathrm{hrs} \\
\text { after admission on strict \& mild criteria, respectively; patients w/o } \\
\text { capacity were older, had higher NIHSS scores, \& more often had } \\
\text { It hemisphere strokes than those deemed capable }\end{array}$ \\
\hline & $\begin{array}{l}\text { Kerrigan } \\
\text { et al., } \\
2012^{19}\end{array}$ & $\begin{array}{l}\text { Retrospec- } \\
\text { tive } \\
\text { cohort }\end{array}$ & $B$ & $\begin{array}{l}\text { Moder- } \\
\text { ate }\end{array}$ & UK & High & $\begin{array}{l}\text { 3.6\% of patients issued Certificate of Incapacity; } 77.8 \% \text { of patients } \\
\text { w/ Certificate of Incapacity had high-grade gliomas, while others } \\
\text { had meningiomas; } 19 \% \text { of patients had preop cognitive assess- } \\
\text { ment documented, } 15.8 \% \text { of whom were issued Certificate of } \\
\text { Incapacity }\end{array}$ \\
\hline & $\begin{array}{l}\text { Knifed et } \\
\text { al., 2008 }\end{array}$ & $\begin{array}{l}\text { Cross- } \\
\text { sec- } \\
\text { tional }\end{array}$ & D & High & Canada & High & $\begin{array}{l}\text { All patients understood purpose of clinical trial; } 29 \% \text { of patients did } \\
\text { not recall any risks of trial drug, while others recalled at most } 4 \\
\text { specific risks or side effects; } 86 \% \text { of patients felt care would not } \\
\text { be compromised if they did not participate in trial, while others } \\
\text { thought they would receive better care if they participated; } 67 \% \text { of } \\
\text { patients indicated they would not make decisions based solely on } \\
\text { physician instructions; } 67 \% \text { of patients indicated they would not } \\
\text { consider withdrawing from study if faced w/ a complication; } 86 \% \\
\text { of patients were satisfied w/ consent process }\end{array}$ \\
\hline & $\begin{array}{l}\text { Krupp et } \\
\text { al., } 2000^{23}\end{array}$ & $\begin{array}{l}\text { Prospec- } \\
\text { tive } \\
\text { cohort }\end{array}$ & $B$ & Low & $\begin{array}{l}\text { Ger- } \\
\text { many }\end{array}$ & High & $\begin{array}{l}\text { Median no. of total recalled risks was } 5 \text { of } 32 \text { in cranial group \& } 4 \text { of } \\
25 \text { in spinal group; } 18 \% \text { of general information retained; } 65 \% \text { of } \\
\text { patients did not recall more than } 2 \text { of } 6 \text { typical major risks; no sig- } \\
\text { nificant correlation btwn recall performance \& age or education }\end{array}$ \\
\hline & $\begin{array}{l}\text { Lo et al., } \\
2017^{25}\end{array}$ & $\begin{array}{l}\text { Prospec- } \\
\text { tive } \\
\text { cohort }\end{array}$ & B & Low & UK & High & $\begin{array}{l}\text { Variation in written documentation of risks, greatest in infection \& } \\
\text { lowest in recurrence, across centers; recall of paralysis as risk } \\
\text { was highest ( } 50.9 \%) \& \text { recurrence was lowest }(6.5 \%) \text {; recall was } \\
\text { significantly greater among individuals aged }<65 \text { yrs than } \geq 65 \\
\text { yrs; patients who consented }>14 \text { days compared to }<2 \text { days } \\
\text { before surgery had higher recall for paralysis \& recurrence; } \\
\text { patient recall was independent of whether consenter was trainee } \\
\text { or consultant }\end{array}$ \\
\hline & $\begin{array}{l}\text { Silva et } \\
\text { al., } 2019^{31}\end{array}$ & $\begin{array}{l}\text { Prospec- } \\
\text { tive } \\
\text { cohort }\end{array}$ & $B$ & Low & US & High & $\begin{array}{l}\text { All parents (or patients when appropriate) understood primary } \\
\text { diagnosis \& type of surgery, } 98 \% \text { understood procedure-specific } \\
\text { risks, \& } 84 \% \text { remembered mention of general risks of surgery; } \\
24 \% \text { of parents recalled that alternative forms of management } \\
\text { had been discussed \& included no treatment; laterality only } \\
\text { documented in } 56 \% \text { of consent forms; all patients believed } \\
\text { informed decision had been made regarding consent to surgery; } \\
12 \% \text { of patients suggested improvements in timing of consent or } \\
\text { presentation of information }\end{array}$ \\
\hline \multirow[t]{2}{*}{$\begin{array}{l}\text { Interven- } \\
\text { tions }\end{array}$} & $\begin{array}{l}\text { Furuno \& } \\
\text { Sa- } \\
\text { sajima, } \\
2015^{15}\end{array}$ & $\begin{array}{l}\text { Uncon- } \\
\text { trolled } \\
\text { before } \\
\& \text { after }\end{array}$ & C & $\begin{array}{l}\text { Moder- } \\
\text { ate }\end{array}$ & Japan & High & $\begin{array}{l}93.8 \% \text { of respondents prefer or strongly prefer use of infographics in } \\
\text { other medical situations; infographics very useful or useful for un- } \\
\text { derstanding brain function \& anatomy by } 81.3 \% \text { of respondents, } \\
\text { pathology of disease by } 75.0 \%, \& \text { doctor's explanation by } 68.8 \%\end{array}$ \\
\hline & $\begin{array}{l}\text { Kondziol- } \\
\quad \text { ka } \\
\text { et al., } \\
2006^{22}\end{array}$ & $\begin{array}{l}\text { Uncon- } \\
\text { trolled } \\
\text { before } \\
\& \text { after }\end{array}$ & C & $\begin{array}{l}\text { Moder- } \\
\text { ate }\end{array}$ & US & High & $\begin{array}{l}100 \% \text { of patients correctly recalled diagnosis \& planned procedure } \\
\text { after specialized consent form \& around } 4.5 \text { mos later; } 98.1 \% \text { of } \\
\text { alternative treatments \& } 97.4 \% \text { of risks recalled correctly after } \\
\text { specialized consent form, compared to } 92.4 \% \text { \& } 91.7 \% \text { around } \\
4.5 \text { mos later; significant reduction in recall rate over time }\end{array}$ \\
\hline
\end{tabular}


» CONTINUED FROM PAGE 5

TABLE 2. Studies included in the review

\begin{tabular}{ccccc}
\hline & Study & Risk of & Income & Key Findings \\
Category & Study & Design & Grade & Bias
\end{tabular}

\begin{tabular}{|c|c|c|c|c|c|c|}
\hline $\begin{array}{l}\text { Interven- } \\
\text { tions } \\
\text { (continued) }\end{array}$ & $\begin{array}{l}\text { Lee et al., } \\
2020^{24}\end{array}$ & $\begin{array}{c}\text { Controlled } \\
\text { before } \\
\& \text { after }\end{array}$ & B & $\begin{array}{l}\text { Moder- } \\
\text { ate }\end{array}$ & Korea & High \\
\hline
\end{tabular}

ean questionnaire scores of patients w/ cervical spondylotic myelopathy due to ossification of pst longitudinal ligament higher in group undergoing educational \& interactive consent process than in standard consent group; $79.4 \%$ of patients selected video as most effective educational \& interactive consent process method; $96.8 \%$ of patients selected video as most effective method of reinforcing verbal communication; patients in educational \& interactive consent group had greater satisfaction $w /$ surgery than those in control group

\begin{tabular}{|c|c|c|c|c|c|}
\hline $\begin{array}{l}\text { Marcus } \\
\text { et al., } \\
2018^{27}\end{array}$ & $\begin{array}{l}\text { Uncon- } \\
\text { trolled } \\
\text { before } \\
\text { \& after }\end{array}$ & C & $\begin{array}{l}\text { Moder- } \\
\text { ate }\end{array}$ & UK & High \\
\hline $\begin{array}{c}\text { Renovanz } \\
\text { et al., } \\
2019^{29}\end{array}$ & $\begin{array}{l}\text { Prospec- } \\
\text { tive } \\
\text { cohort }\end{array}$ & B & $\begin{array}{l}\text { Moder- } \\
\text { ate }\end{array}$ & $\begin{array}{l}\text { Ger- } \\
\text { many }\end{array}$ & High \\
\hline
\end{tabular}

estionnaire scores of knowledge of patients undergoing transsphenoidal excision for pituitary adenoma greater after introduction of interactive educational website; all patients found website easy to understand

Complications/possible postop deficits, prognosis/FU, preop inpatient stay/organizational issues, \& safety of surgical procedure sections of question prompt list had satisfactory internal consistency; unmet information needs greatest for prognosis/FU section; item w/ greatest unmet information need was professional experience of surgeon

\begin{tabular}{|c|c|c|c|c|c|}
\hline $\begin{array}{l}\text { Saigal } \\
\text { et al., } \\
2015^{30}\end{array}$ & $\begin{array}{l}\text { Uncon- } \\
\text { trolled } \\
\text { before } \\
\& \text { after }\end{array}$ & $C$ & $\begin{array}{c}\text { Moder- } \\
\text { ate }\end{array}$ & US & High \\
\hline
\end{tabular}

Median adult spinal deformity patient recall was $45 \%$ immediately after discussion \& video reinforcement about surgery despite ranking consent process as important; median patient recall declined to $18 \%$ at 6-8 wks \& 1 yr postoperatively; perception of severity of complications differed btwn patient \& surgeon; mental status scores showed transient significant decrease from preoperation to discharge but were significantly higher at $1 \mathrm{yr}$ postoperatively

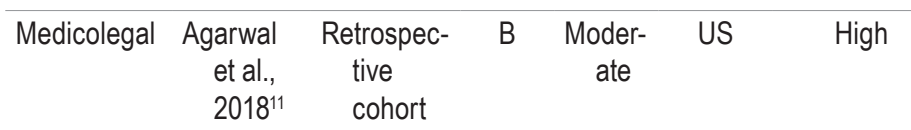

Lack of informed consent noted as factor in $24.4 \%$ of spine surgery malpractice litigation cases; lack of informed consent noted significantly more frequently in elective than emergency cases; failure to diagnose $(31.6 \%)$ \& failure to treat $(32.7 \%)$ also noted in spine surgery malpractice litigation cases; verdict in favor of defendant in $63.3 \%$ of cases; median payments were $\$ 2.5 \mathrm{M}$ for plaintiff verdicts \& $\$ 1.3 \mathrm{M}$ for settlements

\begin{tabular}{|c|c|c|c|c|c|c|}
\hline $\begin{array}{l}\text { Eloy et } \\
\text { al., } \\
2013^{12}\end{array}$ & $\begin{array}{l}\text { Retrospec- } \\
\text { tive } \\
\text { cohort }\end{array}$ & B & $\begin{array}{l}\text { Moder- } \\
\text { ate }\end{array}$ & US & High & $\begin{array}{l}\text { Lack of informed consent noted as factor in favor of defendant in } \\
40.0 \% \text { of endoscopic sinus surgery malpractice litigation cases; } \\
\text { iatrogenic injury ( } 83.3 \%) \text {, permanent deficits ( } 66.7 \%) \text {, \& needing } \\
\text { additional surgery }(63.3 \% \text { ) were other factors noted in cases; } \\
\text { plaintiff won } 36.7 \% \text { of cases, while } 26.7 \% \text { of cases involved } \\
\text { settlement; median payments were } \$ 390 \mathrm{k} \text { for plaintiff verdicts \& } \\
\$ 1 \mathrm{M} \text { for settlements }\end{array}$ \\
\hline $\begin{array}{l}\text { Emery } \\
\text { et al., } \\
2014^{13}\end{array}$ & $\begin{array}{l}\text { Retrospec- } \\
\text { tive } \\
\text { cohort }\end{array}$ & B & $\begin{array}{l}\text { Moder- } \\
\text { ate }\end{array}$ & France & High & $\begin{array}{l}\text { Lack of information noted in } 14 \% \text { of all complaints against neurosur- } \\
\text { geons working in public hospital, including } 29.4 \% \text { of cranial cases } \\
\& 7.4 \% \text { of spinal cases; surgical site infection }(37 \%) \text {, technical } \\
\text { error ( } 22 \%) \text {, delayed diagnosis (11\%), \& lack of supervision }(9 \%) \\
\text { also noted }\end{array}$ \\
\hline $\begin{array}{l}\text { Epstein, } \\
2010^{14}\end{array}$ & $\begin{array}{l}\text { Retrospec- } \\
\text { tive } \\
\text { cohort }\end{array}$ & B & $\begin{array}{l}\text { Moder- } \\
\text { ate }\end{array}$ & US & High & $\begin{array}{l}\text { Lack of informed consent as reason for lawsuit in } 42.6 \% \text { of } \\
\text { malpractice litigation cases involving quadriplegia after cervical } \\
\text { spine surgery; negligent surgery ( } 87.0 \%) \text {, failure to diagnose/treat } \\
(61.1 \%) \text {, \& failure to brace }(27.8 \%) \text { also noted; plaintiff won } 35.2 \% \\
\text { of cases while } 37.0 \% \text { of cases involved settlement; mean pay- } \\
\text { ments were } \$ 5.9 \mathrm{M} \text { for plaintiff verdicts \& } \$ 2.8 \mathrm{M} \text { for settlements }\end{array}$ \\
\hline
\end{tabular}


» CONTINUED FROM PAGE 6

TABLE 2. Studies included in the review

\begin{tabular}{|c|c|c|c|c|c|c|c|}
\hline Category & Study & $\begin{array}{l}\text { Study } \\
\text { Design }\end{array}$ & Grade & $\begin{array}{l}\text { Risk of } \\
\text { Bias }\end{array}$ & Country & $\begin{array}{c}\text { Income } \\
\text { Classification }\end{array}$ & Key Findings \\
\hline \multirow[t]{4}{*}{$\begin{array}{l}\text { Medicolegal } \\
\text { (continued) }\end{array}$} & $\begin{array}{l}\text { Goodkin } \\
\text { \& } \\
\text { Laska, } \\
2004^{16}\end{array}$ & $\begin{array}{l}\text { Retrospec- } \\
\text { tive } \\
\text { cohort }\end{array}$ & B & $\begin{array}{l}\text { Moder- } \\
\text { ate }\end{array}$ & US & High & $\begin{array}{l}1 \text { of } 68 \text { cases of medical litigation for wrong-level disc surgery } \\
\text { involved patient not being informed that wrong-level disc surgery } \\
\text { was conducted; plaintiff verdict rendered in } 18 \text { cases \& defense } \\
\text { verdict in } 13 \text { cases; risk for wrong-level disc space surgery } \\
\text { should be conveyed to patient by surgeon }\end{array}$ \\
\hline & $\begin{array}{l}\text { Kessler } \\
\text { et al., } \\
2019^{20}\end{array}$ & $\begin{array}{l}\text { Retrospec- } \\
\text { tive } \\
\text { cohort }\end{array}$ & B & $\begin{array}{l}\text { Moder- } \\
\text { ate }\end{array}$ & US & High & $\begin{array}{l}\text { Lack of informed consent noted as factor in } 24.4 \% \text { of brain tumor } \\
\text { surgery malpractice litigation cases; failure to diagnose }(28 \%) \text {, } \\
\text { failure to treat (18\%), procedural error ( } 16 \%), \& \text { failure to refer or } \\
\text { order diagnostic tests ( } 14 \% \text { ) also noted; most common diagnoses } \\
\text { included pituitary adenoma (12\%), acoustic neuroma }(12 \%) \text {, \& } \\
\text { meningioma (10\%); plaintiff won } 18 \% \text { of cases, while } 9 \% \text { of cases } \\
\text { involved settlement }\end{array}$ \\
\hline & $\begin{array}{l}\text { Machin } \\
\text { et al., } \\
2018^{26}\end{array}$ & $\begin{array}{l}\text { Retrospec- } \\
\text { tive } \\
\text { cohort }\end{array}$ & B & $\begin{array}{l}\text { Moder- } \\
\text { ate }\end{array}$ & UK & High & $\begin{array}{l}\text { Lack of informed consent noted in } 8.1 \% \text { of spinal surgery mal- } \\
\text { practice litigation cases; most common causes were judgment/ } \\
\text { timing }(52.4 \%) \text {, interpretation of results/clinical picture }(26.1 \%), \& \\
\text { unsatisfactory outcome of surgery (19.6\%); claims estimated to } \\
\text { cost } £ 535.5 \mathrm{M} \text {; cost \& vol of claims trended upward over the } 5-\mathrm{yr} \\
\text { period }\end{array}$ \\
\hline & $\begin{array}{l}\text { Nagashi- } \\
\text { ma } \\
\text { et al., } \\
2017^{28}\end{array}$ & $\begin{array}{l}\text { Retrospec- } \\
\text { tive } \\
\text { cohort }\end{array}$ & $B$ & $\begin{array}{l}\text { Moder- } \\
\text { ate }\end{array}$ & Japan & High & $\begin{array}{l}\text { Lack of informed consent implicated in } 26.9 \% \text { of decisions in favor } \\
\text { of plaintiff from } 2001 \text { to } 2015 \text {, compared to } 26.9 \% \text { for clinical } \\
\text { management, } 19.2 \% \text { for technical skills, } 15.4 \% \text { for negligence in } \\
\text { diagnosis, \& } 11.5 \% \text { for clinical judgment; lack of informed consent } \\
\text { implicated in } 27.8 \% \text { of decisions in favor of plaintiff after } 2016\end{array}$ \\
\hline
\end{tabular}

FU = follow-up; $\mathrm{k}$ = thousand; M = million; NIHSS = National Institutes of Health Stroke Scale; pst = posterior; UK = United Kingdom; US = United States.

ing in $52.4 \%$ of cases, interpretation of results or clinical picture in $26.1 \%$, and unsatisfactory outcome of surgery in $19.6 \% .{ }^{26}$ The estimated cost of all claims was $\leq £ 535.5$ million. ${ }^{26}$ The fourth study determined that the surgeon should convey to the patient that wrong-level disc space surgery is a risk of herniated disc surgery. ${ }^{16}$

\section{Miscellaneous}

Three studies noted that the recall of risks decreased over time. ${ }^{17,22,30}$ Another study determined that patients who consented more than 14 days prior to lumbar spine surgery had greater recall of the risks than those who consented fewer than 2 days before surgery. ${ }^{25}$ The same study found substantial variation in the written documentation of risks across centers performing lumbar spine surgery, with the greatest variation in infection risk and the lowest variation in recurrence risk. ${ }^{25}$ One study found that recall was significantly greater among individuals aged $<65$ years than among those aged $\geq 65$ years, ${ }^{25}$ another noted variations in recall performance based on education level, ${ }^{17}$ and still another study found no significant correlation between recall performance and age or education. ${ }^{23}$ Two studies examined informed consent in the context of clinical trials, one of which determined that the recall of specific risks was limited at baseline,,$^{18}$ while the other concluded that patients with cognitive impairment due to stroke were often incapable of providing consent. ${ }^{21}$

\section{Discussion}

We present a systematic review of informed consent in neurosurgery, the first such study conducted in the field. Our findings underscore the importance of consideration of baseline recall among patients, interventions to enable greater informed consent, and the relationship between informed consent and medical malpractice litigation cases. We highlight strategies that neurosurgeons can employ in patient encounters to increase the likelihood of recall and understanding in informed consent. While neurosurgeons and other members of the healthcare team must ensure informed consent to the best of their abilities, patients have an active role in their care. Improving patient understanding through improved communication strategies and activation of patients to participate in their care may enrich the patient-neurosurgeon relationship, improve health outcomes, and reduce medicolegal liability to neurosurgeons.

\section{Responsibilities of Neurosurgeons}

An important consideration is whether patients have the capacity to provide informed consent. Individuals with cognitive impairment may be unable to provide consent. ${ }^{18,19,24}$ In such cases, obtaining informed consent from a legal representative, either a predesignated healthcare proxy or a party designated by a legislative body, is often required. ${ }^{18}$ Since the principle of informed consent transfers to these legal representatives, neurosurgeons must ensure that the 
legal representatives are optimally informed in these cases, as well as in other situations in which proxies or other legal representatives are present along with the patient.

Additionally, even when patients are considered capable of providing informed consent, their recall after conversations with neurosurgeons regarding surgery is low, particularly the risks of surgery and alternative treatments, including no treatment. ${ }^{17,21,23,25,31}$ Given limitations in patient understanding, the question of the feasibility of informed consent has arisen. Herz et al. posited that informed consent is impossible despite concerted efforts at education on the part of the neurosurgeon with the assistance of a professional educator. ${ }^{17}$ However, the likelihood that a patient does not recall risks or alternatives after a discussion with a neurosurgeon does not release the neurosurgeon from attempting to inform the patient. The responsibility of the neurosurgeon regarding informed consent is to provide the patient with all information pertinent to the medical decision in an optimally comprehensible manner. Although it is unreasonable to expect each patient to fully understand risks and alternatives, improvements in communication between patient and neurosurgeon can increase the effectiveness of the consent process.

The application of informed consent differs across time and place. First, recall decreases over time. ${ }^{17,22,30}$ Although informed consent is typically viewed as a one-time event, the concept of informed consent as a continual process may be more useful and practical. ${ }^{32}$ This frame of reference will underscore the need for neurosurgeons to iteratively inform their patients, both preoperatively and during follow-up visits. Second, the setting often influences the nature of the informed consent process. While outpatient visits and elective surgeries enable the surgeon to explain details of the surgery and the patient or proxy to ask questions, achieving informed consent is particularly difficult in emergency settings given the time pressure, both for patients with the capacity to consent and for the legal representatives of those unable to provide consent. ${ }^{18}$ Alternate strategies such as deferred consent or exceptions to informed consent may be required in emergencies. ${ }^{18}$

\section{Medicolegal Implications}

The lack of informed consent is the basis for a large portion of malpractice lawsuits in neurosurgery. ${ }^{11-14,20,26,28}$ Much weight is placed on documentation of the informed consent process in clinical practice. Although documentation records which information was provided to the patient for future reference, such as in the event of litigation, ${ }^{25,31}$ it is neither a manifestation of informed consent nor complete protection of the surgeon from litigation. ${ }^{22}$ Instead, informed consent is a process by which the physician communicates with the patient about details, risks, benefits, expectations, and alternatives of a given treatment. Documentation serves as an adjunct. The greatest benefit of documentation may be to remind the neurosurgical team of the variety of information to present to patients, both to optimize patient understanding to the extent possible and to indirectly protect against legal liability.

The legal standard in many jurisdictions is to provide all information so that an average, reasonable individual has the information required to make a decision to pur- sue or decline a treatment. ${ }^{17,22}$ The legal standard does not specify which member of the surgical team is responsible for obtaining informed consent. While junior members of the surgical team are often responsible for obtaining consent, this may not be compatible with informed consent; ${ }^{22}$ from this perspective, the attending neurosurgeons should be responsible for obtaining informed consent as the individuals who are performing surgery. Both neurosurgeons and legal systems recognize that consent is rarely fully informed in practice because patients often cannot understand risks and alternatives as well as the surgeon or surgical team. ${ }^{22}$ Neurosurgeons typically disclose the results of relevant diagnostic studies, probable outcome of surgery, perceived benefit of surgery, details of the surgery and postoperative period, probable complications, temporary complications, permanent results and complications, other reasonably common risks, and reasonable alternatives to the procedure along with their risks and benefits. ${ }^{22}$ Patients have the right to refuse or postpone treatment for any reason, even if doing so is considered unreasonable by others, provided that they have been properly informed.

Payments for malpractice litigation in cases of plaintiff verdicts or settlements are extensive, ${ }^{11,12,14}$ with those made in plaintiff verdicts usually greater than those in settlements, particularly for spine surgery. ${ }^{11,14}$ Additionally, legal fees in all lawsuits are high. Discussing all pertinent information to maximize the possibility of informed consent will improve patient safety and outcomes and limit medicolegal liability to neurosurgeons. Other reasons for malpractice litigation, including failure to diagnose or treat, technical error, and complications, ${ }^{11-14,20,26,28}$ should be the focus of quality improvement initiatives as well.

\section{Strategies to Improve the Informed Consent Process}

Maximizing the possibility of informed consent requires consideration of several strategies. Understanding the baseline health literacy level, knowledge, and information needs of each patient regarding the treatment will help neurosurgeons tailor their communication to an appropriate level. ${ }^{29}$ Engaging the patient's support system, including spouses or family members when possible, will improve patient recall through shared family recall. ${ }^{30}$ Using a practice-based consent form written in bullet point form will assist the neurosurgeon by reminding them to discuss important topics. ${ }^{22}$ This form can incorporate the information needs of patients..$^{29}$ Presenting information in multiple modalities, including verbal form, static visuals such as booklets, and dynamic visuals such as video, will increase the probability that patients will recall information conveyed during the encounter. ${ }^{24}$ Using creative and memorable visual aids can improve comprehension further. ${ }^{15}$ Providing the patient with ample events and time to ask questions will maximize opportunities for the necessary clarifications to be made, such as having the patient give consent 2 weeks prior to surgery in elective cases. ${ }^{25}$ Lastly, recall examinations can be used to optimize the consent process by guiding teaching methods, prompting the use of additional educational resources, and directing the neurosurgeon to focus on certain content. ${ }^{30}$ When used together in an interactive manner, these strategies will interact synergistically to improve patient understanding. ${ }^{27}$ 


\section{Study Limitations}

There are several limitations in this review. Only published studies with full-text articles were included, placing the results at risk for publication bias. Studies that show high levels of patient understanding at baseline may be underrepresented in the literature, predisposing our results to an underestimation of patient comprehension. The evidence was of moderate quality given the lack of randomized trials, though it is unlikely a randomized trial could be conducted on this topic. Some studies were at risk of bias because of their retrospective design, while uncontrolled before-and-after studies were prone to bias for similar reasons. Only studies written in or translated into the English language were included, perhaps excluding studies reporting greater patient recall at baseline, interventions that were effective in improving patient recall, and a proportion of malpractice litigation cases predicated on a lack of informed consent in other regions. Additionally, none of the included studies were from low- and middle-income countries, precluding us from determining whether our findings apply in those contexts. Medicolegal studies differed in the possible reasons for litigation, allowing us to determine larger reasons for malpractice lawsuits but preventing granular comparison across studies. Spine surgery was the only subspecialty of neurosurgery with a sufficient number of studies to examine in detail. Additionally, it is difficult to determine from the included studies whether certain provider communication strategies predisposed patients to worse recall, preventing us from isolating the single best communication strategy for most patients. Lastly, no meta-analysis was conducted given the different study designs and outcomes reported across the included studies, allowing us to make assumptions while preventing us from drawing statistically significant conclusions. However, this systematic review represents an important synthesis of the state of informed consent in neurosurgery and provides impetus for action to improve informed consent in neurosurgery for the benefit of patients and providers.

\section{Conclusions}

Informed consent is a controversial yet important facet of clinical practice. We present a systematic review of informed consent and its relevance to medicolegal liability in neurosurgery. Neurosurgeons have a duty to provide patients with all pertinent information to allow them to make a medical decision, though through this process, it may not be possible to guarantee understanding. We examined baseline patient comprehension and capacity, interventions to improve informed consent, and malpractice litigation; it appears that determining the proper capacity to provide informed consent and considering informed consent as a process that depends on the setting are important. There is room to improve the informed consent process centered on baseline patient health literacy and understanding as well as clear communication using multiple modalities. Future directions for research will determine the optimal methods to further enhance patient understanding for shared decision-making in healthcare and also mitigate avoidable medicolegal liability.

\section{References}

1. Schmitz D, Reinacher PC. Informed consent in neurosurgery-translating ethical theory into action. J Med Ethics. 2006;32(9):497-498.

2. Faden RR, Beauchamp TL. A History and Theory of Informed Consent. Oxford University Press; 1986.

3. Berg JW, Appelbaum PS, Lidz CW, Parker LS. Informed Consent: Legal Theory and Clinical Practice. Oxford University Press; 2001.

4. Patterson RH Jr. A code of ethics. The 1986 AANS Presidential Address. J Neurosurg. 1986;65(3):271-277.

5. Black PM. Allocation of medical resources: problems faced by the practicing neurosurgeon. Neurosurgery. 1990;27(1): $156-159$.

6. Scarrow AM, Scarrow MR. Informed consent for the neurosurgeon. Surg Neurol. 2002;57(1):63-69.

7. Moher D, Liberati A, Tetzlaff J, Altman DG. Preferred Reporting Items for Systematic Reviews and Meta-Analyses: the PRISMA Statement. PLoS Med. 2009;6(7):e1000097.

8. The World Bank. World Bank Country and Lending Groups. Accessed September 8, 2020. https://datahelpdesk.worldbank. org/knowledgebase/articles/906519-world-bank-country-andlending-groups

9. Shadish WR, Cook TD, Campbell DT. Experimental and Quasi-Experimental Designs for Generalized Causal Inference. 2nd ed. Houghton Mifflin; 2001.

10. Sterne JA, Hernán MA, Reeves BC, et al. ROBINS-I: A tool for assessing risk of bias in non-randomised studies of interventions. BMJ. 2016;355:i4919.

11. Agarwal N, Gupta R, Agarwal P, et al. Descriptive analysis of state and federal spine surgery malpractice litigation in the United States. Spine (Phila Pa 1976). 2018;43(14):984-990.

12. Eloy JA, Svider PF, D’Aguillo CM, et al. Image-guidance in endoscopic sinus surgery: Is it associated with decreased medicolegal liability? Int Forum Allergy Rhinol. 2013;3(12): 980-985.

13. Emery E, Balossier A, Mertens P. Is the medicolegal issue avoidable in neurosurgery? A retrospective survey of a series of 115 medicolegal cases from public hospitals. World Neurosurg. 2014;81(2):218-222.

14. Epstein NE. A medico-legal review of cases involving quadriplegia following cervical spine surgery: Is there an argument for a no-fault compensation system? Surg Neurol Int. 2010;1:3.

15. Furuno Y, Sasajima H. Medical comics as tools to aid in obtaining informed consent for stroke care. Medicine (Baltimore). 2015;94(26):e1077.

16. Goodkin R, Laska LL. Wrong disc space level surgery: medicolegal implications. Surg Neurol. 2004;61(4):323-342.

17. Herz DA, Looman JE, Lewis SK. Informed consent: Is it a myth? Neurosurgery. 1992;30(3):453-458.

18. Janssen PM, Chalos V, van den Berg SA, et al. Neurological deficits in stroke patients that may impede the capacity to provide informed consent for endovascular treatment trials. $J$ Stroke Cerebrovasc Dis. 2019;28(12):104447.

19. Kerrigan S, Dengu F, Erridge S, et al. Recognition of mental incapacity when consenting patients with intracranial tumours for surgery: How well are we doing? Br J Neurosurg. 2012;26(1):28-31.

20. Kessler RA, Benzil DL, Loewenstern J, et al. Malpractice litigation in brain tumor surgery: a 31-year analysis of causative factors in the United States from the Westlaw database. World Neurosurg. 2019;122:e1570-e1577.

21. Knifed E, Lipsman N, Mason W, Bernstein M. Patients' perception of the informed consent process for neurooncology clinical trials. Neuro Oncol. 2008;10(3):348-354.

22. Kondziolka DS, Pirris SM, Lunsford LD. Improving the informed consent process for surgery. Neurosurgery. 2006; 58(6):1184-1189. 
23. Krupp W, Spanehl O, Laubach W, Seifert V. Informed consent in neurosurgery: patients' recall of preoperative discussion. Acta Neurochir (Wien). 2000;142(3):233-239.

24. Lee Y-S, Cho D-C, Sung J-K, et al. The effect of an educational and interactive informed consent process on patients with cervical spondylotic myelopathy caused by ossification of the posterior longitudinal ligament. Spine (Phila Pa 1976). 2020;45(3):193-200.

25. Lo WB, McAuley CP, Gillies MJ, et al. Consent: an event or a memory in lumbar spinal surgery? A multi-centre, multispecialty prospective study of documentation and patient recall of consent content. Eur Spine J. 2017;26(11):2789-2796.

26. Machin JT, Hardman J, Harrison W, et al. Can spinal surgery in England be saved from litigation: a review of 978 clinical negligence claims against the NHS. Eur Spine J. 2018;27(11): 2693-2699.

27. Marcus HJ, Jain A, Grieve J, Dorward NL. Informed consent for patients undergoing transsphenoidal excision of pituitary adenoma: development and evaluation of a procedure-specific online educational resource. World Neurosurg. 2018;118: e933-e937.

28. Nagashima H, Wada Y, Hongo K. Trend of malpractice litigation against neurosurgeons in Japan: an analysis of disclosed database by courts in Japan from 2001 through 2015. Neurol Med Chir (Tokyo). 2017;57(8):426-432.

29. Renovanz M, Haaf J, Nesbigall R, et al. Information needs of patients in spine surgery: development of a question prompt list to guide informed consent consultations. Spine J. 2019; 19(3):523-531

30. Saigal R, Clark AJ, Scheer JK, et al. Adult spinal deformity patients recall fewer than $50 \%$ of the risks discussed in the informed consent process preoperatively and the recall rate worsens significantly in the postoperative period. Spine (Phila Pa 1976). 2015;40(14):1079-1085.
31. Silva AHD, Wijesinghe H, Mundil N, et al. Consent in paediatric neurosurgery: adequacy of documentation and parental perspectives. Childs Nerv Syst. 2019;35(12):2363-2369.

32. Lidz CW, Appelbaum PS, Meisel A. Two models of implementing informed consent. Arch Intern Med. 1988;148(6): $1385-1389$.

\section{Disclosures}

The authors report no conflict of interest concerning the materials or methods used in this study or the findings specified in this paper.

\section{Author Contributions}

Conception and design: all authors. Acquisition of data: Shlobin. Analysis and interpretation of data: Shlobin. Drafting the article: all authors. Critically revising the article: all authors. Reviewed submitted version of manuscript: all authors. Approved the final version of the manuscript on behalf of all authors: Lam. Administrative/technical/material support: Lam, Sheldon. Study supervision: Lam, Sheldon.

\section{Supplemental Information Videos \\ Video Abstract. https://vimeo.com/466124990.}

\section{Correspondence}

Sandi Lam: Anne and Robert H. Lurie Children's Hospital, Northwestern University Feinberg School of Medicine, Chicago, IL.sandilam@gmail.com. 